364

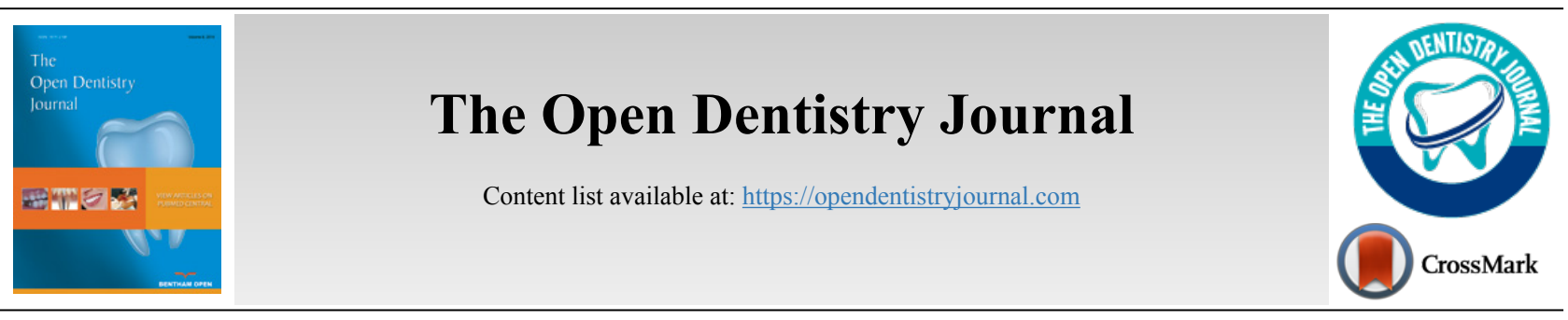

RESEARCH ARTICLE

\title{
Influence of the Arabic-Coffee on the Overall Color of Glazed or Polished Porcelain Veneers - In vitro Study
}

Nabiel Alghazali ${ }^{1}$, Afaf A. Hakami ${ }^{2}$, Ghadah A. AlAjlan ${ }^{3}$, Rawan M. Alotaibi ${ }^{4}$, Faris N. Alabdulwahab, Lama A. AlQuraishi ${ }^{3}$, Hadeel Abdalkadeer ${ }^{6}$ and Mohammed M. Al Moaleem ${ }^{7, *}$

\author{
${ }^{1}$ Department of Prosthodontics, Aleppo University, Aleppo, Syria \\ ${ }^{2}$ College of Dentistry, Jazan University, Jazan, SA \\ ${ }^{3}$ Interne, Princess Norah Bint Abdulrahman University PNU, Riyadh, SA \\ ${ }^{4}$ College of Dentistry, Dar Al Uloom University. Riyadh, $S A$ \\ ${ }^{5}$ College of Dentistry, King Saud University, Riyadh, SA \\ ${ }^{6}$ College of Dentistry, Damascus University, Damascus, Syria \\ ${ }^{7}$ Department of Prosthetic Dental Science, Jazan University, Jazan, SA
}

\begin{abstract}
:
Background:

Sometimes, porcelain restorations experience some degree of colour change in oral environment, which could be related to the quality of diet and surface roughness of these restorations.

\section{Objective:}

The aim of this in-vitro study was to evaluate the influence of Arabic-Coffee on the overall color of glazed or polished porcelain veneers fabricated from four different porcelain materials and two different thicknesses.

\section{Materials and Methods:}

A total of 160 porcelain disc of tested specimens were fabricated to a standardized thickness of $1.00 \mathrm{~mm}$ and $0.6 \mathrm{~mm}$ using the following materials: Feldspathic porcelain, Zircon, E-max Press, and E-max CAD; ( 80 discs for each thickness and 20 specimens of each material used). Veneer specimens from each material were randomly divided into two subgroups $(n=10)$ : 10 specimens were kept as glazed, were the other 10 tested specimens were adjusted with diamond burs, and then polished with Ivoclar Vivadent ceramic polishing kits using the recommended protocol for polishing provided by the company. A color of all tested specimens was measured using Vita Easy Shade Spectrophotometer. Then, all specimens were immersed in Arabic coffee (Al Mosafer Coffee, Saudi Arabia) and theromcycled for 1 week, and the colors of all tested specimens were then recorded again.

Results:

It was shown that there is a significant difference in the average color changes before and after immersing in Arabic-Coffee for all materials and thicknesses used in the current study. In-addition, significant differences in color changes were noticed between glazed and polished specimens.

Moreover, colour change caused by the coffee was not significantly related to the thickness of the specimens used.

Conclusion:

Color stability of porcelain materials could be affected by surface treatment whether glazing or polishing. All aesthetic restorations should be deglazed whenever any adjustments have been done to maintain the color match and stability in an oral environment. Also, Arabic-Coffee is considered as a staining drink to a limited extend where patient should be assured to maintain their oral health to maintain the colour stability of their restorations.
\end{abstract}

Keywords: Arabic-coffee, Color stability, Glazed ceramic, Polishing, Ceramic, Feldspathic porcelain, Color measurements. 


\section{INTRODUCTION}

Teeth appearance has become a growing concern to the majority of patients. And it may have an effect on patients' psychology (i.e. confidence and self-esteem) [1 - 6]. One option for aesthetic restoration is ceramic veneers which can be used in several aesthetic treatments to improve tooth shape, color, contour, size, and malalignment [7, 8]. In a survey, 91\% of dental practitioners, identified veneers as an ethical choice to treat aesthetic problems. Based on their strength, longevity, texture, conservative nature, good wear resistance, biocompatibility, aesthetics, porcelain veneers have been considered as an ultimate option for conservative aesthetic treatment modalities $[9,10]$.

Several materials are being used to fabricate ceramic veneers including: feldspathic porcelain and glass-based ceramics [11]. Feldspathic porcelain has been widely used to fabricate porcelain veneers, and it has continued to be the material of choice in some aesthetic cases. Moreover, since the introduction of lithium di-silicate E-max system, it becomes one of the best materials to fabricate porcelain veneers. Moreover, Zircon based ceramic is considered the material of choice in some cases to fabricate porcelain veneers, especially when we have deeply discolored teeth.

It is important to achieve an acceptable color match between the natural teeth and the aesthetic restorations; however, it is also essential to maintain such color match in oral environment. Several studies have assessed the color stability in relation to the surface texture of different restorative materials [12]. Ceramic surfaces adjustment can remove the glazed layer, which reveals the pores of the ceramic material, creating a rough surface and may lead to discoloration of the restoration that requires re-glazing or polishing after grinding [13 - 19] Many studies have proven that polishing of grinded porcelain provides as smooth surface as glazed one which may even be esthetically better. Moreover, some studies supported the use of polishing as an alternative to glazing [13]. On the other hand, some studies demonstrated that porcelain staining is correlated with diet, immersion time along with type of surface treatments $[12,20]$

Moreover, it is not clearly stated yet if that the porcelain thickness is considered a significant factor in surface discoloration of ceramic veneers. However, majority of studies reported the importance of ceramic thickness in masking or showing the discoloration of underlying resin cement rather than the discoloration of the ceramic material itself $[9,12,13]$.

In a study was done by Gupta et al. to evaluate color stability of a porcelain materials after exposure to commonly consumed beverages i.e. tea, coffee, and Coca-Cola, it has been concluded that porcelain veneers is affected by dietary habits [20]. Furthermore, coffee is considered to be the most beverage cause discoloration to porcelain veneer [21, 22].

In fact, Coffee is known as one of the most popular beverages worldwide. Saudi population consumes a special type of coffee so-called: Arabic-Coffee. It contains some addi-

* Address correspondence to this author at the Department of Prosthetic Dental Science, Jazan University, Jazan, SA; Tel: +00966- 550599553;

E-mail: drmoaleem2014@gmail.com tives including: Saffron, Ginger and Cardamom. And it has been suggested that it might be a staining factor to aesthetic restorations $[23,24]$.

The value of average Colour change $(\Delta \mathrm{E})$, is clinically important, and challenging in different levels of colour measrments. It has been shown that the borderline $\Delta \mathrm{E}^{*}$ which is perceptible to all people in a color test is 2.5 [25]. A scale of perceptible color difference has also been proposed with a $\Delta \mathrm{E}^{*}$ $<1$ regarded as not appreciable to the human eye and a $\Delta \mathrm{E}^{*}>$ 2 appreciable by non-skilled persons and therefore of clinical significance [26]. Moreover, it has been found that 3.3 units of color difference have been considered unacceptable by $50 \%$ of observers. Similarly, $50 \%$ of observers had rejected the color difference of $2.72 \Delta \mathrm{E}$ units between the samples [27]. Additionally, an in vivo study has shown that the average $\Delta \mathrm{E}^{*}$ between teeth assessed to be a complete color match intraorally is 3.28 While the average $\Delta \mathrm{E}^{*}$ of 6.8 units has been assessed to present the clinically color mismatch [28]. However, a recent in vivo study has presented the clinically acceptable threshold to be $\Delta E^{*} 4.2$ units [29 - 33]. Therefore, $\Delta \mathrm{E}^{*}$ perceptible and clinically acceptable thresholds should be borne in mind when assessing restorations spectrophotometrically. This study aims to evaluate the influence of Arabic-Coffee on the overall color of glazed or polished porcelain veneers fabricated from four different porcelain materials and two different thicknesses.

\section{MATERIALS AND METHODS}

\subsection{Study Design}

A total of 160 ceramic disc specimens of $10 \mathrm{~mm}$ diameter were prepared for this study. Ceramic discs were produced to a standardized thickness of $1.00 \mathrm{~mm}$ (80 samples) and $0.6 \mathrm{~mm}$ (80 samples) using the following materials (20 samples of each material): Feldspathic, Zircon, E-max press, and E-max CAD (Table 1). Veneer Specimens from each material were divided into two subgroups $(\mathrm{n}=10)$ according to the surface management: polished or glazed.

Table 1. Materials used in the study.

\begin{tabular}{|c|c|c|c|}
\hline Material & $\begin{array}{c}\text { Type } \\
\text { (brand name) }\end{array}$ & Manufacture & Shades \\
\hline Feldspathic & $\begin{array}{c}\text { Enamel Vita } \\
\text { VM 13 }\end{array}$ & $\begin{array}{c}\text { (Vita, Zahnfabrik, Bad } \\
\text { Sackigen, Germany) }\end{array}$ & Shade: B1 \\
\hline Zircon & $\begin{array}{c}\text { Ceramill Zolid } \\
\text { PS }\end{array}$ & $\begin{array}{c}\text { (Aman Girrbach, } \\
\text { Germany) }\end{array}$ & $\begin{array}{c}\text { Shade: B } \\
\text { light }\end{array}$ \\
\hline Emax press & $\begin{array}{c}\text { IPS Ema Press } \\
\text { HT }\end{array}$ & $\begin{array}{c}\text { (Ivoclar Vivadent, } \\
\text { Liechtenstein) }\end{array}$ & Shade: B1 \\
\hline Emax CAD & $\begin{array}{c}\text { IPS Emax CAD } \\
\text { HT }\end{array}$ & $\begin{array}{c}\text { (Ivoclar Vivadent, } \\
\text { Liechtenstein) }\end{array}$ & Shade: B1 \\
\hline
\end{tabular}

Color was measured with the samples placed on gray background using vita Easy shade spectrophotometer. Then all specimens were immersed in Arabic coffee for four weeks, and the colors of all specimens were measured again. A flow chart demonstrated the study design and specimens distribution Fig. (1). 


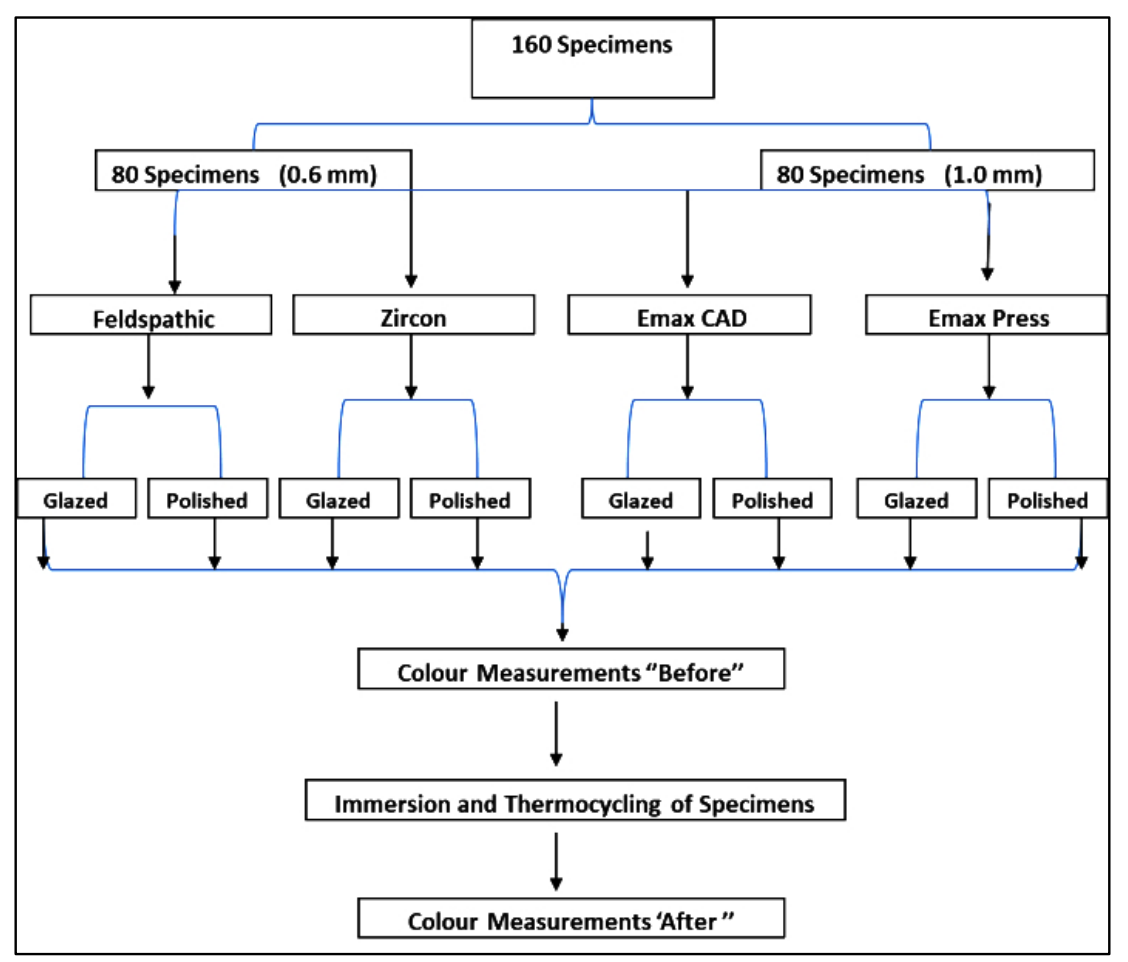

Fig. (1). Flow chart showing the study design and distribution of the tested specimens.

\subsection{Specimens Fabrication}

For the first group, specimens of shade B1 enamel feldspathic ceramic (Vita, Germany) were fabricated by a single operator using two Teflon molds with a diameter of 10 $\mathrm{mm}$ and a depth of $1.1 \mathrm{~mm}$ and $0.7 \mathrm{~mm}$ respectively. These shades were selected as such light shades are the most used shades in porcelain veneers fabrication. Both the porcelain and modeling liquid were mixed, packed and dried and then placed onto platinum foil and fired according to the manufacturer's instruction. Specimens were then glazed according to the company instructions.

For the second group, presintered zirconia blocks attached to the milling machine (Amann Girrbach, Germany) to produce 20 specimens of $10 \mathrm{~mm}$ diameter $\times 0.6 \mathrm{~mm}$ and 20 specimens of $10 \mathrm{~mm}$ diameter $\times 1.00 \mathrm{~mm}$ thickness), and then samples were glazed according to the manufacturer's recommendations.

For the third group, 40 specimens were made, designed from IPS Emax CAD, and milled into the desired dimensions using the CAM milling machine (Amann Girrbach, Germany) and then were crystallized and glazed according to the manufacturer instructions.

For the last group, test specimens of IPS Emax Press were fabricated from casting wax (Ivoclar Vivadent) using same Teflon mould. Then these discs were invested and heated to melt the wax away, and then IPS E-max ceramic were pressed and then glazed according to the manufacturer's recommendations.

Both surfaces of the specimens (Feldspathic and E-max Press) were finished using abrasive papers to give a finished thickness of $1.0 \mathrm{~mm}+/-0.025 \mathrm{~mm}$ and $0.6+/-0.025$ (measured with digital calipers and rejected if outside given range).
Colour measurements for all tested specimens were then recorded by single operator and considered as a baseline colour readings.

\subsection{Materials' Surface Treatments}

Tested specimens of each thickness and material were divided into 2 subgroups: First subgroup specimens were glazed according to the manufacturer's instructions for each material, where the other subgroup specimens were adjusted with diamond burs then polished with ceramic polishing kit (Ivoclar Vivadent) using the recommended protocol for polishing provided by the company.

\subsection{Color Measurements}

Color measurements were made using an 'Easy shade' Vita probe spectrophotometer (Vita Easy shade, Vita, Germany). Spectrophotometers measure CIE-LAB values giving a numerical representation of a $3 \mathrm{D}$ measure of color. These measurements have been previously used in studies assessing shades of both porcelain and teeth. Readings of $\mathrm{L}^{*}, \mathrm{a}^{*}$ and $\mathrm{b}^{*}$ were performed three times against the same (gray) background and the mean value used. Means of color data with the standard deviations of tooth surfaces were calculated.

\subsection{Immersion of Tested Specimens in the Arabic-Coffee}

All the tested specimens were immersed in an ArabicCoffee (Almosafer Coffee, Saudi Arabia) for four weeks. During this immersion period, an ageing process was conducted using a thermocycling machine where 10 cycles were accomplished every day; first in $5^{\circ} \mathrm{C}$ cold water and then in $55{ }^{\circ} \mathrm{C}$ hot water (Ivoclar Vivadent). The all the tested specimens were then dipped in distilled water following removal from the Arabic-Coffee drink solution, and moved up 
and down for 10 times. The tested specimens were then wiped dry with tissue paper, and then placed in viewing port for color measurement. Colors were measured again by the same operator, same settings and same gray background.

\subsection{Data Analysis}

SPSS 22.0 software (Chicago, USA) and excel Microsoft 10 were used to insert the data. Data were analyzed to determine any differences in the colour of the tested specimens after immersion in coffee, and difference in colour change between glazed and polished groups, and difference in colour change in between $0.6 \mathrm{~mm}$ and $1.00 \mathrm{~mm}$ specimens. To determine these differences, one-way analysis of variance (ANOVA) and T-test analytical tests were used at $P$-value of $0.05[34,35]$. Then comparing colour change values to the perceptible threshold 2.8 and clinically acceptable threshold $4.2[31]$.

The $\Delta \mathrm{E}^{*}$ values were calculated for the different materials and thicknesses using the following equation:

$\Delta \mathrm{E}^{*}=\left[\left(\mathrm{L}_{1}{ }^{*}-\mathrm{L}_{2}{ }^{*}\right)^{2}+\left(\mathrm{a}_{1}{ }^{*}-\mathrm{a}_{2}{ }^{*}\right)^{2}+\left(\mathrm{b}_{1}{ }^{*}-\mathrm{b}_{2}{ }^{*}\right)^{2}\right]^{1 / 2}$

\section{RESULTS}

For $0.6 \mathrm{~mm}$ thick samples (Table 2 and Graph $\mathbf{1}$ ); the mean $\Delta \mathrm{E}^{*}$ of the Feldspathic porcelain samples was (1.5) for the glazed group and (4.92) for the polished group. Where Mean $\Delta \mathrm{E}^{*}$ for Zircon samples was (1.82) for the glazed group and (4.35) for the polished group. Mean $\Delta \mathrm{E}^{*}$ for E-max Press was (1.92) for the glazed group and (5.57) for the polished group. Finally Mean $\Delta \mathrm{E}^{*}$ of the Emax Press was (1.58) for the glazed group and (5.53) for the polished group.

For $1.0 \mathrm{~mm}$ thickness (Table 3 and Graph 2); the mean $\Delta \mathrm{E}^{*}$ of the Feldspathic porcelain samples was 1.26 for the glazed group and 4.23 for the polished group. Where $\Delta \mathrm{E}^{*}$ of the Zircon samples was 1.261 for the glazed group and 4.34 for the polished group. Mean $\Delta \mathrm{E}^{*}$ of the Emax Press was 1.54 for the glazed group and 4.15 for the polished group. Finally, Mean $\triangle \mathrm{E}^{*}$ of the Emax $\mathrm{CAD}$ was 1.68 for the glazed group and 4.21 for the polished group.

Table 2. Means and SDs of color change for $0.6 \mathrm{~mm}$ thickness of all materials.

\begin{tabular}{|c|c|c|c|c|c|c|c|c|}
\hline \multirow{2}{*}{\begin{tabular}{|c|} 
Materials \\
Used
\end{tabular}} & \multicolumn{2}{|c|}{ Feldispathic } & \multicolumn{2}{|c|}{ Zircon } & \multicolumn{2}{|c|}{ Emax Press } & \multicolumn{2}{|c|}{ Emax CAD } \\
\hline & - & - & - & - & - & - & - & - \\
\hline Surface & Glazed & Polished & Glazed & Polished & Glazed & Polished & Glazed & Polished \\
\hline- & - & - & - & - & - & - & - & - \\
\hline $\begin{array}{c}\text { Mean } \\
\Delta \mathrm{E}^{*}\end{array}$ & 1.5 & 4.92 & 1.82 & 4.35 & 1.92 & 5.57 & 1.58 & 5.53 \\
\hline- & - & - & - & - & - & - & - & - \\
\hline STDEV & 0.50 & 0.29 & 0.28 & 0.52 & 0.57 & 0.44 & 0.46 & 0.41 \\
\hline$P$-value & \multicolumn{2}{|c|}{$P \leq 0.01$} & \multicolumn{2}{|c|}{$P \leq 0.01$} & \multicolumn{2}{|c|}{$P \leq 0.01$} & \multicolumn{2}{|c|}{$P \leq 0.01$} \\
\hline
\end{tabular}

Based on analysis tests; significant differences in color change were noticed before and after immersing with coffee for all materials and thicknesses used $(p<0.01)$. Significant differences in color changes were noticed between glazed and polished specimens $(p<0.01)$. No significant differences in color change were noticed when using different thickness for all materials used $p \geq 0.05$ ).

Table 3. Means and SDs of color change for $1.0 \mathrm{~mm}$ thickness for all materials used.

\begin{tabular}{|c|c|c|c|c|c|c|c|c|}
\hline $\begin{array}{c}\text { Materials } \\
\text { Used }\end{array}$ & Feldspathic & \multicolumn{2}{c|}{ Zircon } & \multicolumn{2}{c|}{ Emax Press } & \multicolumn{2}{c|}{ Emax CAD } \\
\hline- & - & - & - & - & - & - & - & - \\
\hline Surface & Glazed & Polished & Glazed & Polished & Glazed & Polished & Glazed & Polished \\
\hline- & - & - & - & - & - & - & - & - \\
\hline $\begin{array}{c}\text { Mean } \\
\Delta E^{*}\end{array}$ & 1.26 & 4.23 & 1.261 & 4.34 & 1.54 & 4.15 & 1.68 & 4.21 \\
\hline- & - & - & - & - & - & - & - & - \\
\hline STDEV & 0.41 & 0.58 & 0.57 & 0.61 & 0.57 & 0.62 & 0.46 & 0.50 \\
\hline$P$-value & \multicolumn{2}{|c|}{$P \leq 0.01$} & \multicolumn{2}{|c|}{$P \leq 0.01$} & \multicolumn{2}{c|}{$P \leq 0.01$} & \multicolumn{2}{c|}{$P \leq 0.01$} \\
\hline
\end{tabular}

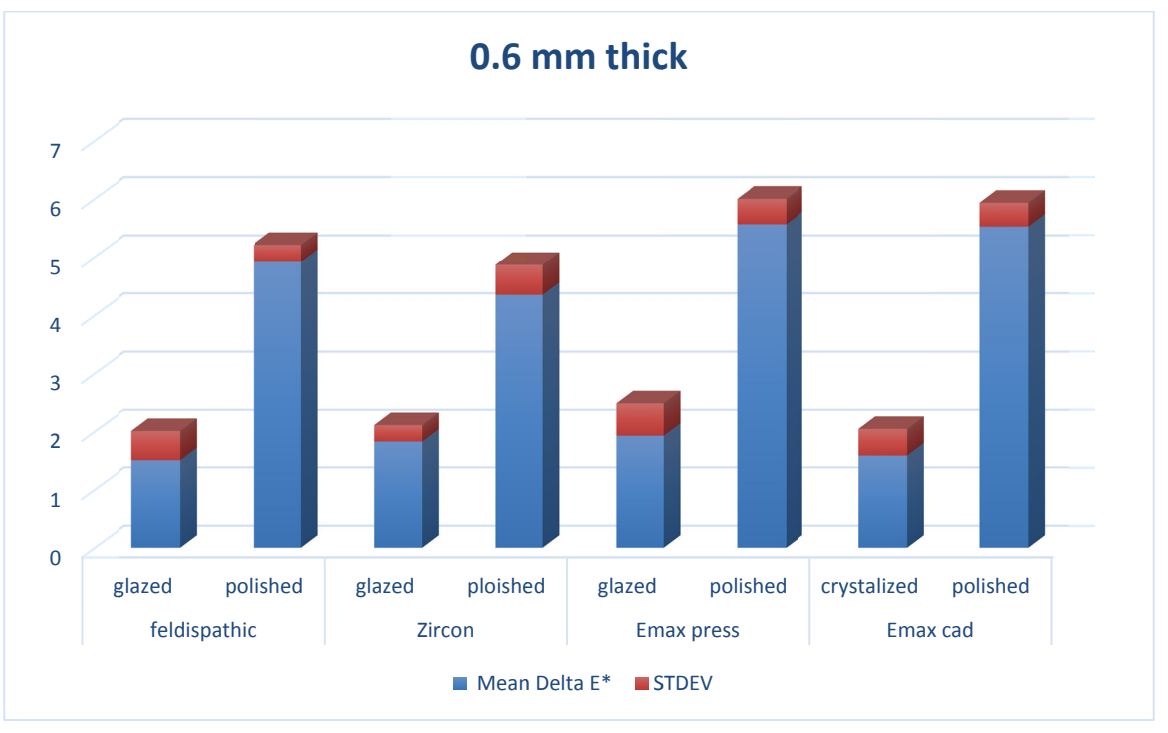

Graph. (1). Colour changes of $0.6 \mathrm{~mm}$ thick samples for all materials used. 


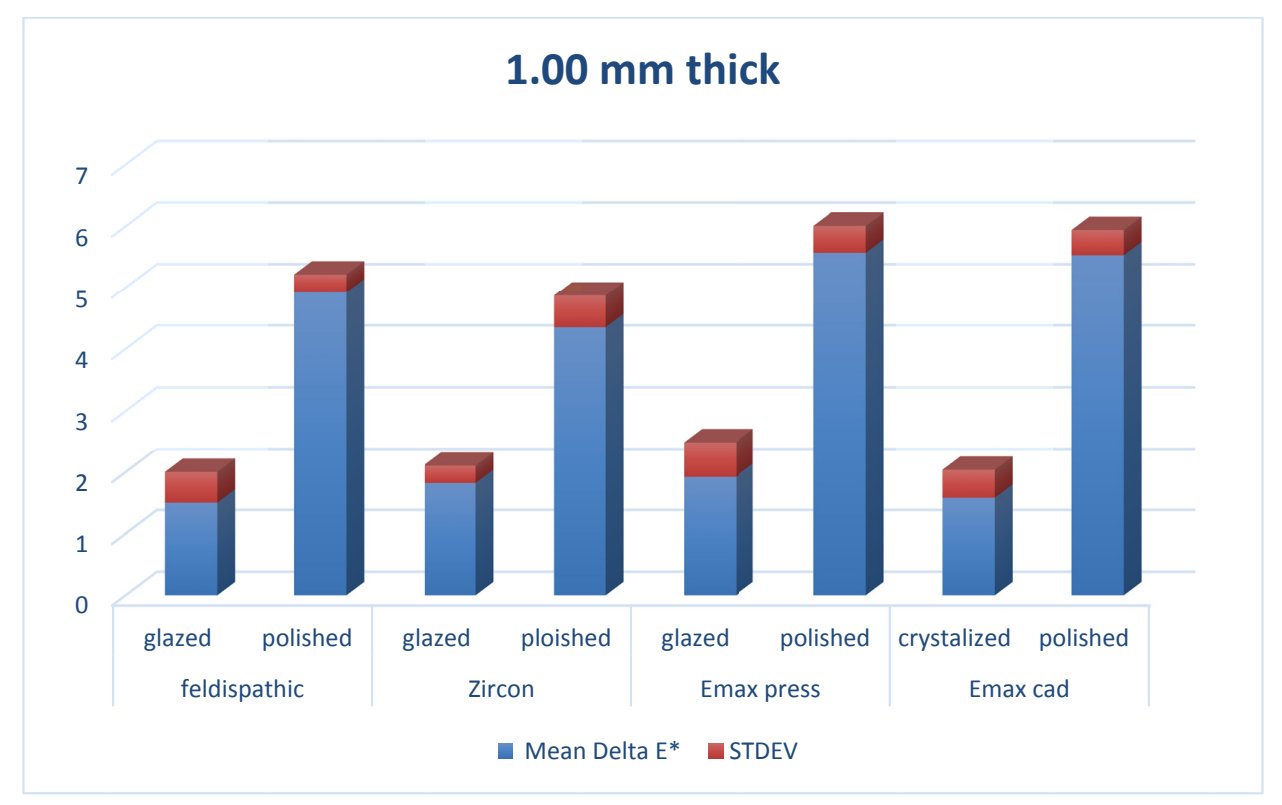

Graph. (2). Colour changes of $1.00 \mathrm{~mm}$ thick samples for all materials used.

\section{DISCUSSION}

Nowadays patients demand for aesthetic restorations with long-term color stability to enhance their teeth appearance $[1-6]$. These considerations have led to the use of all-ceramic materials. Which still can experience some degrees of colour changes related to some consumed foods or beverages?

Arabic-Coffee is considered one of these staining drinks as it has special additive ingredients [23, 24]. This current study was conducted to evaluate the effect Arabic coffee on the overall all color of glazed and polished porcelain specimens fabricated from different porcelain material and two different thicknesses. Statistically significant differences were noticed for all tested specimens after immersion in this type of Coffee, which assures the fact that this Arabic Coffee is considered as a staining factor for porcelain restorations and patients, in their turns, supposed to be instructed to clean their teeth well after consumption of such coffee in an attempt to maintain the colour stability of their restorations.

In considerable number of cases, dentists tend to do some adjustments of their aesthetic restorations, and some of them tend to or prefer to do only polishing while neglecting to do the glazing step. Based on that, we attempted in this current study to compare the color changes of polished and glazed porcelain specimens. Noticed significant differences in color changes between glazed and polished specimens were noticed for all ceramic materials used, and for both thicknesses. This assures the importance of glazing any ceramic restoration after doing any type of adjustments, even when doing a proper polishing protocol.

Several studies have demonstrated the relationship between the color changes and ceramic thickness. Bulent Uludag et al. conducted a study to evaluate the effect of ceramic thickness on the color stability, and concluded that as the ceramic thickness increased, significant decreases in $\Delta \mathrm{E}^{*}$ values were recorded [36, 37]. However, in this study, no significant difference in color change was noticed when using different thicknesses of all porcelain materials used. This might be explained by different study settings used in different studies.

Furthermore, in most specimens, the colour changes of glazed materials were less than the perceptibility threshold (2.8). This confirms the fact that porcelain materials experience limited and imperceptible colour change to the human eye despite the statistically significant difference caused by ArabicCoffee. While the colour changes of the polished specimens were above the perceptibility threshold and even above the acceptability threshold (4.2) in most specimens which demonstrate that such colour changes are clinically unacceptable to the human eye [38]. This, again, assures the importance of glazing all aesthetic restorations before cementing them into the patient's mouth.

Clinicians have to put in his consideration the possible color changes that might result after any intra-oral adjustment followed by polishing procedures to the ceramic surface. Inaddition, it is usually preferable to reglaze the all ceramic restorations after any surface treatments and before final cementation.

\section{CONCLUSION}

Different porcelain materials used have shown a difference in terms of color change after immersing in Arabic-Coffee. The difference between glazed and polished porcelain specimens were obvious for all materials and thicknesses used. The average color change was not significant with different thicknesses. Color change of polished specimens where remarkably higher than those of glazed specimens and was clinically unacceptable, which suggest glazing of all aesthetic restorations after any adjustments might be done and before cementation to maintain the color match in oral environment.

\section{ETHICS APPROVAL AND CONSENT TO PARTICIPATE}

Not applicable 


\section{HUMAN AND ANIMAL RIGHTS}

No animals/humans were used for studies that are the basis of this research.

\section{CONSENT FOR PUBLICATION}

Not applicable.

\section{AVAILABILITY OF DATA AND MATERIALS:}

All data supporting this article are available with Dr Mohammed M. Al Moaleem on reasonable request.

\section{FUNDING}

None.

\section{CONFLICT OF INTEREST}

The authors declare no conflict of interest, financial or otherwise.

\section{ACKNOWLEDGEMENTS}

Declared none.

\section{REFERENCES}

[1] Kelly JR, Nishimura I, Campbell SD. Ceramics in dentistry: historical roots and current perspectives. J Prosthet Dent 1996; 75(1): 18-32. [http://dx.doi.org/10.1016/S0022-3913(96)90413-8] [PMID: 9005250]

[2] Dietschi D. Layering concepts in anterior composite restorations. J Adhes Dent 2001; 3(1): 71-80. [PMID: 11317387]

[3] Joiner A. Tooth colour: A review of the literature. J Dent 2004; 32(1)(Suppl. 1): 3-12. [http://dx.doi.org/10.1016/j.jdent.2003.10.013] [PMID: 14738829]

[4] Leinfelder KF. Porcelain esthetics for the $21^{\text {st }}$ century. J Am Dent Assoc 2000; 131(Suppl.): 47S-51S

[http://dx.doi.org/10.14219/jada.archive.2000.0402] [PMID: 10860 345]

[5] Vallittu PK, Vallittu ASJ, Lassila VP. Dental aesthetics--A survey of attitudes in different groups of patients. J Dent 1996; 24(5): 335-8. [http://dx.doi.org/10.1016/0300-5712(95)00079-8] [PMID: 8916647]

[6] Carlsson GE, Wagner IV IV, Odman P, et al. An international comparative multicenter study of assessment of dental appearance using computer-aided image manipulation. Int J Prosthodont 1998; 11(3): 246-54 [PMID: 9728119]

[7] Davis LG, Ashworth PD, Spriggs LS. Psychological effects of aesthetic dental treatment. J Dent 1998; 26(7): 547-54. [http://dx.doi.org/10.1016/S0300-5712(97)00031-6] [PMID: 9754742]

[8] McLaren EA, Whiteman YY. Ceramics: Rationale for material selection. Compend Contin Educ Dent 2010; 31(9): 666-8. [PMID: 21197936]

[9] Douglas RD. Color stability of new-generation indirect resins for prosthodontic Application. J Prosthet Dent 2000; 83(2): 166-70. [http://dx.doi.org/10.1016/S0022-3913(00)80008-6] [PMID: 106 68028]

[10] McLaren EA, LeSage B. Feldspathic veneers: What are their indications? Compend Contin Educ Dent 2011; 32(3): 44-9. [PMID: 21560742]

[11] Singh K, Suvarna S, Agnihotri Y, Sahoo S, Kumar P. Color stability of aesthetic restorative materials after exposure to commonly consumed beverages: A systematic review of literature. Eur J Prosthodont 2014; 2(1): $15-22$.

[http://dx.doi.org/10.4103/2347-4610.122989]

[12] Kursoglu P, Karagoz Motro PF, Kazazoglu E. Correlation of surface texture with the stainability of ceramics. J Prosthet Dent 2014; 112(2): 306-13

[http://dx.doi.org/10.1016/j.prosdent.2013.09.028] [PMID: 24484857]

[13] Van Noort R. Introduction to dental materials. $4^{\text {th }}$ ed. Edinburgh: Mosby 2013; p. 264

[14] Motro PF, Kursoglu P, Kazazoglu E. Effects of different surface treatments on stainability of ceramics. J Prosthet Dent 2012; 108(4): 231-7.

[http://dx.doi.org/10.1016/S0022-3913(12)60168-1] [PMID: 2303 1729]

[15] Klausner LH, Cartwright CB, Charbeneau GT. Polished versus autoglazed porcelain surfaces. J Prosthet Dent 1982; 47(2): 157-62. [http://dx.doi.org/10.1016/0022-3913(82)90180-9] [PMID: 7035652]

[16] Raimondo RL Jr, Richardson JT, Wiedner B. Polished versus autoglazed dental porcelain. J Prosthet Dent 1990; 64(5): 553-7. [http://dx.doi.org/10.1016/0022-3913(90)90126-W] [PMID: 2090814]

[17] Goldstein GR, Barnhard BR, Penugonda B. Profilometer, SEM, and visual assessment of porcelain polishing methods. J Prosthet Dent 1991; 65(5): 627-34.

[http://dx.doi.org/10.1016/0022-3913(91)90196-4] [PMID: 2051383]

[18] Fuzzi M, Zaccheroni Z, Vallania G. Scanning electron microscopy and profilometer evaluation of glazed and polished dental porcelain. Int $J$ Prosthodont 1996; 9(5): 452-8

[PMID: 9108746]

[19] al-Wahadni A, Martin DM. Glazing and finishing dental porcelain: A literature review. J Can Dent Assoc 1998; 64(8): 580-3. [PMID: 9785688]

[20] Gupta R, Prakash H, Shah N, Jain V. Spectrophotometric evaluation of color changes of various tooth colored veneering materials after exposure to commonly consumed beverages. J Indian Prosthodont Soc 2005; 5: $72-8$.

[http://dx.doi.org/10.4103/0972-4052.16873]

[21] Koksal T, Dikbas I. Color stability of different denture teeth materials against various staining agents. Dent Mater J 2008; 27(1): 139-44. [http://dx.doi.org/10.4012/dmj.27.139] [PMID: 18309623]

[22] Douglas RD. Color stability of new-generation indirect resins for prosthodontic application. J Prosthet Dent 2000; 83(2): 166-70. [http://dx.doi.org/10.1016/S0022-3913(00)80008-6] [PMID: 10668 028]

[23] Gross MD, Moser JB. A colorimetric study of coffee and tea staining of four composite resins. J Oral Rehabil 1977; 4(4): 311-22. [http://dx.doi.org/10.1111/j.1365-2842.1977.tb00997.x] [PMID: 269 919]

[24] Yannikakis SA, Zissis AJ, Polyzois GL, Caroni C. Color stability of provisional resin restorative materials. J Prosthet Dent 1998; 80(5): 533-9.

[http://dx.doi.org/10.1016/S0022-3913(98)70028-9] [PMID: 9813802]

[25] Hosoya Y. Five-year color changes of light-cured resin composites: Influence of light-curing times. Dent Mater 1999; 15(4): 268-74. [http://dx.doi.org/10.1016/S0109-5641(99)00046-9] [PMID: 1055 1095]

[26] Kuehni RG, Marcus RT. An experiment in visual scaling of small color differences. Color Res Appl 1979; 4: 83.

[27] Seghi RR, Hewlett ER, Kim J. Visual and instrumental colorimetric assessments of small color differences on translucent dental porcelain. J Dent Res 1989; 68(12): 1760-4.

[http://dx.doi.org/10.1177/00220345890680120801] [PMID: 2600257]

[28] Ruyter IE, Nilner K, Moller B. Color stability of dental composite resin materials for crown and bridge veneers. Dent Mater 1987; 3(5): 246-51.

[http://dx.doi.org/10.1016/S0109-5641(87)80081-7] [PMID: 3479360]

[29] Ragain JC Jr, Johnston WM. Color acceptance of direct denta restorative materials by human observers. Color Res Appl 2000; 25: 278-85.

[http://dx.doi.org/10.1002/1520-6378(200008)25:4<278::AID-COL8> 3.0.CO;2-F]

[30] Johnston WM, Kao EC. Assessment of appearance match by visual observation and clinical colorimetry. J Dent Res 1989; 68(5): 819-22. [http://dx.doi.org/10.1177/00220345890680051301] [PMID: 2715476]

[31] Douglas RD, Steinhauer TJ, Wee AG. Intraoral determination of the tolerance of dentists for perceptibility and acceptability of shade mismatch. J Prosthet Dent 2007; 97(4): 200-8. [http://dx.doi.org/10.1016/j.prosdent.2007.02.012] [PMID: 17499089]

[32] ALGhazali N, Laukner J, Burnside G, Jarad FD, Smith PW, Preston AJ. An investigation into the effect of try-in pastes, uncured and cured resin cements on the overall color of ceramic veneer restorations: An in vitro study. J Dent 2010; 38(2)(Suppl. 2): e78-86. [http://dx.doi.org/10.1016/j.jdent.2010.08.013] [PMID: 20801184]

[33] Karayazgan B, Atay A, Saracli MA, Gunay Y. Evaluation of Candida albicans formation on feldspathic porcelain subjected to four surface treatment methods. Dent Mater J 2010; 29(2): 147-53. [http://dx.doi.org/10.4012/dmj.2009-016] [PMID: 20379024]

[34] Tholt de Vasconcellos B, Miranda-Júnior WG, Prioli R, Thompson J, 
Oda M. Surface roughness in ceramics with different finishing techniques using atomic force microscope and profilometer. Oper Dent 2006; 31(4): 442-9.

[http://dx.doi.org/10.2341/05-54] [PMID: 16924984]

[35] Ruyter IE, Nilner K, Moller B. Color stability of dental composite resin materials for crown and bridge veneers. Dent Mater 1987; 3(5): 246-51.

[http://dx.doi.org/10.1016/S0109-5641(87)80081-7] [PMID: 3479360]

[36] Seghi RR, Hewlett ER, Kim J. Visual and instrumental colorimetric assessments of small color differences on translucent dental porcelain.
J Dent Res 1989; 68(12): 1760-4.

[http://dx.doi.org/10.1177/00220345890680120801] [PMID: 2600257]

[37] Uludag B, Usumez A, Sahin V, Eser K, Ercoban E. The effect of ceramic thickness and number of firings on the color of ceramic systems: An in vitro study. J Prosthet Dent 2007; 97(1): 25-31.

[http://dx.doi.org/10.1016/j.prosdent.2006.11.002] [PMID: 17280888]

[38] Kim H-K, Kim S-H, Lee J-B, Han J-S, Yeo I-S. Effect of polishing and glazing on the color and spectral distribution of monolithic zirconia. J Adv Prosthodont 2013; 5(3): 296-304.

[http://dx.doi.org/10.4047/jap.2013.5.3.296] [PMID: 24049571]

\section{(C) 2019 Alghazali et al.}

This is an open access article distributed under the terms of the Creative Commons Attribution 4.0 International Public License (CC-BY 4.0), a copy of which is available at: (https://creativecommons.org/licenses/by/4.0/legalcode). This license permits unrestricted use, distribution, and reproduction in any medium, provided the original author and source are credited. 